\title{
関東における伝統工芸の原材料と産地に関する研究
}

\section{The Relationship between Raw Materials and Producing Areas of Folk Crafts in Kanto Distinct}

\author{
丸谷 耕太* 土肥 真人* 杉田 早苗*
}

\section{Kota MARUYA Masato DOHI Sanae SUGITA}

\begin{abstract}
This study focused on traditional crafts manufactured in Kanto district and investigated the relationship between raw materials used and the origins of these materials. Analyses revealed that more than half of the traditional crafts are made from the raw materials transported from areas outside. A proportion of crafts relying solely on supplies from their local areas has decreased to none. While artisans who has been using the raw materials all supplied from outside since establishment were more flexible in where the raw materials come from, artisans who had previously obtained the raw materials within their local areas expressed needs for obtaining raw material within their locals. These results suggested a necessity of separate policies differing in raw material supplies at establishment, and a necessity to expand and improve production network for conservation of skills of traditional crafts.
\end{abstract}

Keywords: Traditional Craft, Row Material ,Producing Areas, Cooperative Association キーワード：伝統的工芸品，原材料，産地，組合

\section{1. はじめに}

\section{(1) 研究の背景と目的}

伝統工芸は、重要な地場産業として、固有の技術とともに各地 で長年にわたって継承されてきた。20 世紀後半の高度経済成長期 以降、伝統工芸に対しては産業振興と地域経済発展の観点から 様々な支援策が講じられてきた。しかし、安価な代替物の登場や 原材料の入手難等、産業の観点からは現在も多くの問題を抱えて いる。一方、伝統工芸の生産活動は文化的景観の要素と認識され 1)、活動の場としての産地の風景は文化的景観として捉えられ始 めた ${ }^{2)}$ 。原材料を生産するための森林や畑といった自然の風景、 陶磁器を生産するための登り窯が集まる集落といった生産工程が 作り出寸風景等、伝統工芸は目に映る地域特有の景観を作り出し ているといえよう。さらに、地域で採れる自然の原材料を用いる ことの多い伝統工芸は、近年のSATOYAMA イニシアティブ等で注目

\section{表- 1 調査対象の概要}

\begin{tabular}{|c|c|c|c|c|c|c|c|}
\hline ID & 品名 & 都道府県 & 種類 & 指定年 & 企業総数 & 従事者数 & $\begin{array}{l}\text { 年生産額 } \\
\text { (百万的) }\end{array}$ \\
\hline (1) & 結城紬 & 茨城県、杤木県 & 織物 & 1977 & 343 & 517 & 1070 \\
\hline (2) & 笠間焼 & 茨城県 & 陶磁器 & 1992 & 284 & 400 & 2000 \\
\hline (3) & 真壁石燈籠 & 茨城県 & 石工品 & 1995 & 201 & 1094 & 7000 \\
\hline (4) & \begin{tabular}{|l|l} 
益子焼 \\
\end{tabular} & 杤木県 & 陶磁器 & 1979 & 360 & 800 & 3000 \\
\hline (5) & 伊勢崎絣 & 群馬県 & 織物 & 1975 & 29 & 1103 & 600 \\
\hline (6) & 桐生織 & 群馬県 & 織物 & 1977 & 261 & 1755 & 4714 \\
\hline (7) & 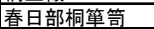 & 埼玉県 & 木工品 & 1979 & 12 & 48 & 400 \\
\hline (8) & 江戸木目込人形 & 埼玉県、東京都 & 人形 & 1978 & 35 & 1150 & 2700 \\
\hline (9) & 岩槻人形 & 埼玉県 & 人形 & 2007 & 160 & 1040 & 9270 \\
\hline (10) & 房州うちわ & 千葉県 & 竹工品 & 2003 & 6 & 70 & 58 \\
\hline (11) & 村山大島紬 & 東京都 & 織物 & 1975 & 25 & 90 & 50 \\
\hline (12) & 本場黄八丈 & 東京都 & 織物 & 1977 & 62 & 65 & 88 \\
\hline (13) & 多摩織 & 東京都 & 織物 & 1980 & 85 & 226 & 2001 \\
\hline (14) & 東京染小紋 & 東京都 & 染色品 & 1976 & 23 & 94 & 524 \\
\hline (15) & 笨京手描友禪 & 東京都 & 染色品 & 1980 & 80 & 112 & 500 \\
\hline (16) & 江戸指物 & 東京都 & 木工品 & 1997 & 25 & 36 & 200 \\
\hline (17) & 江戸和笔 & 東京都 & 竹工品 & 1991 & 34 & 120 & 450 \\
\hline (18) & 東京銀器 & 東京都 & 金工品 & 1979 & 103 & 237 & 1480 \\
\hline (19) & 江戸節句人形 & 笨京都 & 人形 & 2007 & 41 & 163 & 3362 \\
\hline$(20)$ & 江戸からかみ & 東京都 & 染色品 & 1999 & 13 & 84 & 1000 \\
\hline (21) & 江戸切子 & 東京都 & その他 & 2002 & 78 & 135 & 900 \\
\hline (22) & 江戸木版画 & 笨京都 & その他 & 2007 & 60 & 120 & 5000 \\
\hline (23) & 鎌倉彫 & 神奈川県 & 木工品 & 1979 & 72 & 187 & 954 \\
\hline (24) & 小田原漆器 & 神奈川県 & 木工品 & 1984 & 11 & 29 & 150 \\
\hline (25) & 箱根寄木細工 & 神奈川県 & 木工品 & 1984 & 36 & 119 & 567 \\
\hline
\end{tabular}

される、二次的自然環境の保全と持続的な地域資源の利用という 新たな視点から注目すべき対象だと考えられる。

このように、新たな観点からの伝統工芸の再検討により伝統工 芸の維持や支援策に新しい方向性が提示されることが期待できる。 そこで本研究は、持続的な地域資源利用と文化的景観保全の観点 から支援策を検討寸るうえでの知見を得るため、伝統工芸の生産 工程を把握し原材料と産地の関係の変遷を明らかにし、それらに 対する生産者の意識を明らかにすることを目的とする。

伝統工芸の産地に関寸る既往研究としては、伝統的工芸品の地 域振興への利用を論じた研究 ${ }^{3445)}$ 、産地形成や構造の分析を行っ た研究 ${ }^{6778)}$ がある。また、循環型地域モデルに関する研究は多数 ある ${ }^{910)}$ が、持続的な地域資源利用や文化的景観の保全に視点を 置いた研究は管見では見当たらない。

\section{(2) 研究の対象}

全国では 1275 品目の伝統工芸が確認されているが 11)、本研究 では、「伝統的工芸品産業の振興に関する法律」(以下、伝産法) によって指定されている工芸品 210 品目のうち関東地方に存在す る 25 品目を対象とする (表一 1 )。

\section{(3) 研究の方法と構成}

工芸品の材料には原材料と中間生産物の 2 種類がある。本研究 では、自然から直接とれる材料を原材料、原材料が加工されて材 料となるものを中間生産物と定義し、分析を行う。

まず、産地に関する論理と施策の変遷を整理し、つぎに、本論 の対象とする伝統的工芸品について、指定時に産地組合が作成し た申出書 ${ }^{12)}$ を調査資料として工程図を作成し ${ }^{13)}$ 、産地の分業の類 型化を行い 14)、用いられる原材料及びその原材料の産地内調達の 有無を調査する。さらに、経済産 業省により伝統的工芸品の認定を 受けた産地組合にアンケート調查 を行い(表-2)、指定時から現在 までの原材料の変化を把握し、変

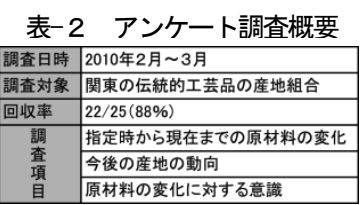

*東京工業大学大学院社会理工学研究科 
化に対する各産地の意識を分析する。最後に総合的考察を行う。

\section{2. 伝統工芸と産地に関わる考え方及び施策の変遷}

1974 年に制定された「伝産法」は日本で初めて二次産業に関わ る産地を指定し地域的に支援を行った。その後、産地は一定の産 業集積地と認識され、1997 年の「特定産業集積の活性化に関寸る 臨時措置法」まで、その対象を拡大しながら産業支援がなされて きた。産地の捉え方についても、清成忠男は産地の特徴として、 地域的な企業集団・社会的分業・在来産業または在来化した外来 産業からの発展・伝統的に経営資源が蓄積されてきた消費財の特 産品工業を挙げているが 15)、伊賀光屋は共同体や伝統の存在それ 自体は産地の要件とは考えないと主張している 16)。

一方、2001年の「伝産法」改正により、産地としての伝統工芸 は地域振興に貢献寸る産業や環境に優しい産業として位置づけら れると共に、2005 年の改正文化財保護法による文化的景観の保護 が提唱され、産地は文化的景観としても認識され始めた。同時に、 SATOYAMA イニシアティブに代表される自然共生型社会を目 指寸動きの中で自然資源の伝統的な利用法の再評価が進んでいる。

\section{3. 伝統的工芸品の原材料}

\section{（1）生産工程の類型（図-1）}

伝統的工芸品を生産工程の分類に従い整理すると、垂直型・垂 直 $+\alpha$ 型・水平型・垂直水平併合型といら計 4 種に類型化される。 垂直型は 14 品目と最も多い。垂直+ $\alpha$ 型は 5 品目あり、水平型は 3 品目であり、垂直水平併合型は 4 品目であった。

\section{（2）原材料と産地}

伝統的工芸品に使用される原材料と産地内での生産の有無を工 芸品の種類ごとにまとめた（表-3）。原材料の多寊は各工芸品に よってそれぞれだが、種類ごとにみると、木工品は多種の木材を 利用しており、人形はその部品の多さから様々な原材料を利用寸 る傾向にある。原材料と産地の関係を見ると、全ての原材料を産 地内でまかなっている工芸品は存在しない。産地内と産地外の原 材料を併用している産地は 12 ヶ所あり、残りの 13 ヶ所の産地は 全ての原材料を産地外から仕入れて製造を行っている。

表-3 伝統的工芸品の原材料

\begin{tabular}{|c|c|c|c|c|c|c|c|c|}
\hline ID & 工芸品名 & 種類 & 草·樹 & 土·石 & 鉱物 & 動物 & その他 & 合計 \\
\hline (1) & 結城紬 & \multirow{6}{*}{ 織物 } & 1 & & & & & 1 \\
\hline (5) & 伊勢崎絣 & & $7(1)$ & & & & 3 & $10(1)$ \\
\hline (6) & 桐生織 & & $2(2)$ & & 2 & & 1 & $5(2)$ \\
\hline (11) & 村山大島紬 & & $3(1)$ & & & & 1 & $4(1)$ \\
\hline (12) & 本場黄八丈 & & $6(5)$ & $1(1)$ & & & & $7(6)$ \\
\hline (13) & 多摩織 & & 8 & & & & 1 & 9 \\
\hline (14) & 東京染小紋 & \multirow{3}{*}{ 染色品 } & $7(1)$ & & & & 1 & $8(1)$ \\
\hline (15) & 東京手描友禅 & & 3 & & & & 2 & 5 \\
\hline (20) & 江戸からかみ & & 6 & & 2 & & 3 & 11 \\
\hline (2) & 笠間焼 & \multirow{2}{*}{ 陶磁器 } & $3(3)$ & $11(10)$ & & & $5(3)$ & $19(16)$ \\
\hline (4) & 益子焼 & & 3 & 9 & & & 5 & 17 \\
\hline (3) & 真壁石燈籠 & 石工品 & & $5(3)$ & & & & $5(3)$ \\
\hline (7) & 春日部桐䇤笴 & \multirow{5}{*}{ 木工品 } & $7(3)$ & 1 & 3 & $1(1)$ & & $12(4)$ \\
\hline (16) & 江戸指物 & & 7 & 1 & & & & 8 \\
\hline (23) & 鎌倉彫 & & 21 & 3 & 1 & & 5 & 30 \\
\hline (24) & 小田原漆器 & & 5 & & & & & 5 \\
\hline (25) & 箱根寄木細工 & & 37 & & & 1 & 1 & 39 \\
\hline (10) & 房州うちわ & \multirow{2}{*}{ 竹工品 } & $8(4)$ & & & $1(1)$ & & $9(5)$ \\
\hline (17) & 江戸和筸 & & 8 & & & & 2 & 10 \\
\hline (18) & 東京銀器 & 金工品 & & & 20 & & & 20 \\
\hline$(8)$ & 江戸木目込人形 & \multirow{3}{*}{ 人形 } & $7(1)$ & 4 & 2 & 2 & 3 & $18(1)$ \\
\hline (9) & 岩槻人形 & & $12(1)$ & & 1 & 2 & 1 & $16(1)$ \\
\hline (19) & 江戸節句人形 & & $14(2)$ & & $7(2)$ & $6(1)$ & $1(1)$ & $28(6)$ \\
\hline (21) & 江戸切子 & \multirow{3}{*}{ その他 } & & 3 & & & & 3 \\
\hline (22) & 江戸木版画 & & 3 & & & & & 3 \\
\hline \multicolumn{2}{|c|}{ 合計 } & & $178(24)$ & $38(14)$ & $38(2)$ & $13(3)$ & $35(4)$ & $302(47)$ \\
\hline & 産地内で採れる害 & & $13.5 \%$ & $36.8 \%$ & $5.2 \%$ & $23.1 \%$ & $11.4 \%$ & $15.6 \%$ \\
\hline
\end{tabular}

注：（）内は産地内で採れる原材料の数

\section{（3）中間生産物之産地}

材料に占める中間生産物の割合を産地ごとにみると、30\%未満 の産地が 10 ヶ所ある一方で $50 \%$ 以上の産地は 14 ヶ所と半数以 上を占める。特に染色品や人形、織物は割合が高い（表一4）。ま た伝統的工芸品における中間生産物は 125 種中 91 種（73\%）が
産地外で生産されていることも明らかになった。

\section{表-4＼cjkstart材料における中間生産物の割合}

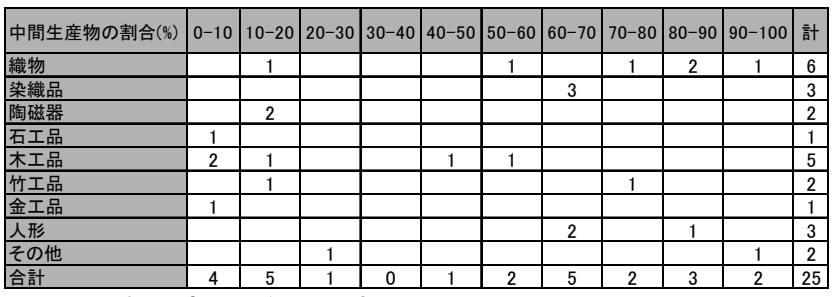

\section{4. 原材料の変化と組合の意識}

\section{(1) 指定時から現在までの変化}

伝産法に指定された後に原材料に変化があった産地（表-5）は 10 ヶ所あった。全原材料 302 種中 38 種（13\%）の原材料がこれ らの産地で変化していた。そのうち、「使用しなくなった」ものが 12 種、「産地外で作るようになった」ものが 15 種、「新しい素材 になった」ものが 9 種である。このような変化の要因としては、 性質のよい原材料が生まれたこと、原材料の生産者の減少による 入手難が指摘されている ${ }^{17)}$ 。また、工芸品を製作する際の技法に 変化があったのは、春日部桐篎笥のヤシャブシ ${ }^{18)}$ のであり、製 品の質に変化があったのは春日部桐篂笥のイボタロウ虫とウツギ の変化 ${ }^{19)}$ のであった。他の工芸品に関しては、技法や製品の質 を変化させずに対応していることが分かる。

\section{表-5 指定時から現在までの材料の変化}

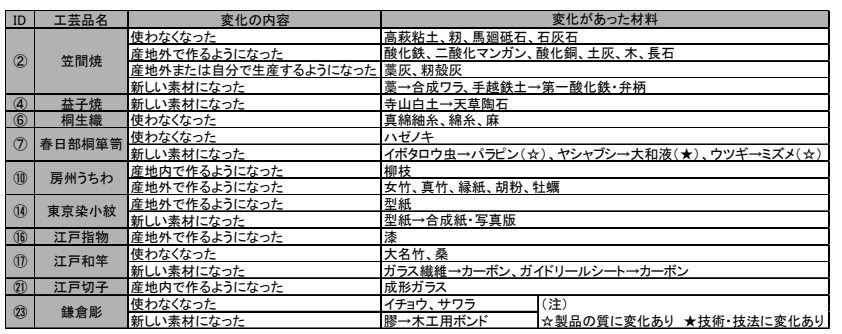

\section{（2）各産地での原材料の変化}

産地の成立時と伝産法への指定時及び現在の、全原材料におけ る各産地内で採孔る原材料の割合の変遷及び将来への意向は (図一 2）のようになる。全て産地外の原材料を一貫して使用し加工の みを行っている産地が半数あり (21 ヶ所中 11 ヶ所)、将来の意向 も全て現状維持である。

一方、残りの 10 ケ所は産地内で入手可能な原材料を使用して いる。産地成立時には産地内で全ての原材料をまかなっていた産 地は８所存在していたが、今ではその全てが他産地の原材料も 一部利用している。将来への意向では現状の継続が望まれている。

\section{（3）産地や原材料に対する組合の意識}

\section{(i ）伝統的に使用されてきた原材料の変化}

原材料について、「今後も変化してはいけない」と回答した産地 が 11 件と最も多く、「一部の原材料は変わってはいけないとい う意見は6件ある。これら歴史的な原材料を大切と考える産地が 多い中、「原材料は変わってもよい」という産地も 4 件ある。工芸 品の種類別に見ると、全ての織物は原材料の変化に対して否定的

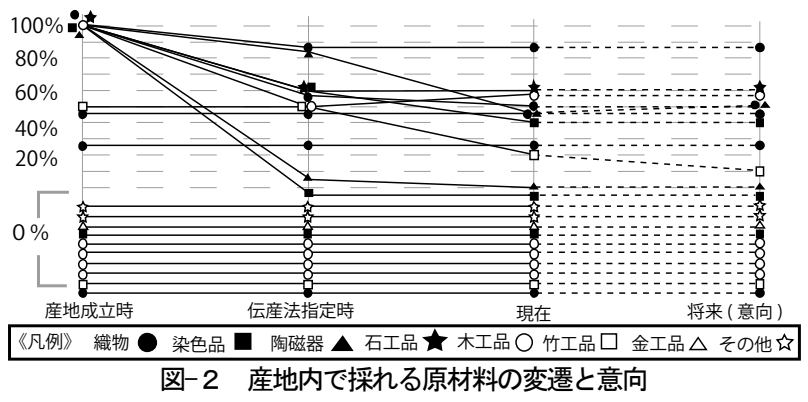







であり、木工品の多くと竹工品は一部の原材料を大切にしている。

\section{(ii ) 原材料の調達先の変化}

原材料の調達先について、「すべての原材料が変化してはいけな いと感じている産地は 9 件あるが、「原材料が同じであれば他産 地でもよい」という意見も同数ある。一方、調達先は「変わって もよい」という意見は 4 件ある。産業種別の傾向を見ると、殆ど の織物は原材料の調達先が変わってはいけないと感じているのに 対し、「変わってもよい」という意見は全て木工品であった。

\section{（iii）産地外の原材料への志向}

産地外に良い原材料があれば「是非利用したい」または「どち らかといえば利用したい」という意見が計 16 件ある。「利用した くない」と答えた 5 件の産地に比べその数は多かった。織物や石 工品、竹工品は産地外の原材料の利用に消極的な傾向にある。

(4) まとめ

産地成立時には原材料を全て産地内で生産していた産地も時 代とともに産地外の原材料を利用するようになった (8 ヶ所)。現 在も産地内で生産している織物等の 9 万所の産地は産地外の原材 料の使用に抵抗を感じている。一方で、成立時から産地外のもの を使用している木工品等の産地（9 ケ所）は産地外に良い原材料 があれば利用したいと考える傾向にある。

\section{5. 総合的考察}

関東地方の伝統的工芸品は、技術や製品の質を保ちつつも、伝 産法指定後に全体で $13 \%$ の原材料が変化した。生産工程と原材料 の間や工芸品と産地組合の意識の間の強い相関は看取できないが （表－6）、産地成立時に産地内の原材料を使用していた産地は原 材料の変化に対して否定的であり、産地外から全ての原材料を入 手してきた産地は原材料の変化に対して柔軟な傾向にある。

産地と原材料の関係について、約半数にあたる 10 ケ所の産地に おいて産地内の材料が変化していることが分かった。そのうち、 成立時から指定時までに変化した産地が 3 ヶ所（結城紬、江戸和 竿、本場黄八丈)、指定時から現在までに変化した産地が 5 ケ所(房 州うちわ、笠間焼、江戸切子、益子焼、江戸指物)、成立時から指 定時、指定時から現在までともに変化している産地が 2 ヶ所（桐

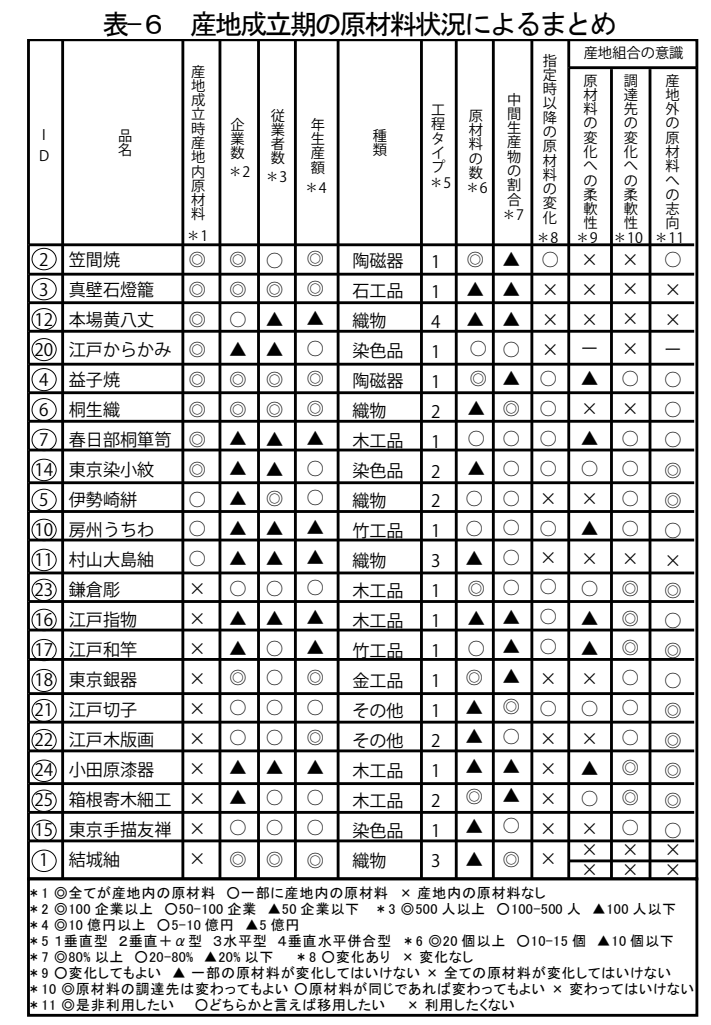

生織、春日部桐箪笥）ある。

また、産地が变化した材料のうち、中間生産物は 11 種あり 20 ) 原材料は 30 種 (草・樹 19 種、土・石 4 種、鉣物 3 種、動物 2 種、 その他 2 種) あった。後者に関しては産地内で工芸品とつながり を持っていた原材料が作り出していた景観の消失を招いていると 考えられる ${ }^{21)}$

土・石や鉱物などは持続的な資源でないため、現存する原材料 の採掘とともに質の近い代替品の調査や搬入の支援が求められる。 一方で、草・樹や動物など持続可能な原材料に関しては、産業と しての伝統工芸を維持していくためにはより安価、もしくはより 良質の原材料が必要になる場合もある。しかし、その場合でも一 部であれ産地内での調達を復活させ、伝統的な地域とのつながり を目に見える景観として復原させることは伝統工芸の存続や景観 の保全に資すると考えられる。具体的には、産地の意識に即しな がら、労働者となる職人や環境に対して以下のような支援の方向 性が挙げられる。既に使用しなくなった産地内の原材料に関して は、それを加工する技法を携えた職人の技法を絶やさぬように、 早急に労動環境を整えて後継者の育成を図り技法を継承していか なければならない。同時に、原材料となる植物を安定的に利用可 能なまでに生育するには一般に長い時間を要するため、長期的な 支援が必要となる。また、産地における一次産業と二次産業の連 携を密にしていく必要がある。

謝辞 : 本研究にあたり、財団法人大林都市研究振興財団の平成 21 年度奨励研究助成を受けた。記して謝意を表します。

\section{補注及び引用文献}

1）山口知恵、松本将一郎、西山德明（2009）: 子鹿田焼の里皿山におりる伝統的な生 業の持続と文化的景観の保全に関寸る研究 : 日本建築学会計画系論文集第 74 巻第 644 号、2215-2222

2）黛卓郎、石垣良弘 (2006) : 歴史・文化・風土を活かした地域づくりとランドスケ 一プ技術 : ランドスケープ研究第 70 号、24-27

3) 大西隆 (1980) : 地場産業都市における地域開発の課題: 都市計画学会論文集第 15 号、133-138

4）玉井明子、久隆浩（1999）: 地場産業都市における観光活動設計とまちづくりに関 寸る研究一愛知県常滑市栄町を事例として一: 都市計画学会論文集第 34 号、355-360

5）戸田和宏、渡辺貴介 (1997) : 伝統的工芸品の観光的活用手法に関寸る研究 : 都市 計画学会論文集第 32 号、271-276

6）北村嘉行 (2006)：工芸産業の地域 : 原書房

7）井上秀次郎 (2004)：地域活性化のための地場産業研究 : 唯学書房

8) 上野和彦 (2007) : 地場産業産地の革新 : 古今書院、41-51pp

9）上原三知、重松敏則、朝野景 (2005) : 都市近郊里地・里山林の保全・活用による 潜在的生産力とその循環型地域モデル : ランドスケープ研究第 68 号、545-550

10）原科幸爾、武内和彦：長野県佐久市を事例とした地域循環型の生物資源利用シス テムに関する研究 : ランドスケープ研究第 67 号、741-744

11）財伝統的工芸品産業振興協会 (2007) : 全国伝統的工芸品総覽 : 同友館

12）申出書には、工芸品名、用途、製造工程、使用される材料・道具、製造される地 域並びに製造業者数及び従業者数が記載されている。

13）工程図は以下の定義に基づいて作成した。(1)申出書の詳細な工程に従う(2)各工程 をまとめる大項目がある場合はそれに従う(3)平行して行う工程は並列して表す(4)工 程と使用される原材料及び中間生産物を線で結ぶ(5)産地の境界線を記入する。

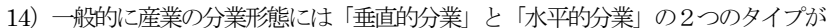
あることが指摘されている。また、中小企業金融公庫調查部が行った調査「地場産 業の変容とそこに生きる中小企業の対応 (2003 年 2 月) 4-5pp」でも、地場産業の 分業について「垂直構造」と「水平構造」を分けて分析している。

15）清成忠男（1980）：地域社会と地場産業：日本経済評論社、113pp

16）伊賀光屋 (2000）: 産地の社会学 : 多賀出版、373-377 pp

17）財伝統的工芸品産業振興協会（2008）: 現代に生きる伝統工芸 : ぎょうせい、 130-134pp

18）ヤシャブシを採取する人がいなくなり、科学的に製造された大和液を代用してい る。大和液の方が安く簡単で安定している。

19）イボタロウ虫はパラピンに代わり、ウツギは入手が困難となり高価になったため に代用品としてミズメを使用するようになった。

20）産地において中間生産物の生産がなくなることは、その生産技法の消失を意味寸 ると考えられるが、その復活については稿を改めて検討する必要がある。

21）例えば、笠間焼では、産土や石は有限であり枯渇することを考慮すると産地外の 代替品への車換はや先を得ない。一方で、施舳に用いる天然の木や橖や籾は高価に なったために合成物で代用しており、木や橖を採取する山や田の風景、木や葍を燃 やして灰を作る風景が産地から消失したと言える。 